Gut, 1985, 26, 232-236

\title{
Acid and gastrin responses during intragastric titration in normal subjects and duodenal ulcer patients with G-cell hyperfunction
}

\author{
R G COOPER, G J DOCKRAY, J CALAM, AND R WALKER \\ From the MRC Secretory Control Group, Physiological Laboratory, and Department of Medicine, University \\ of Liverpool, and Gastrointestinal Unit, Walton Hospital, Liverpool
}

SUMMARY Amino acid induced acid and gastrin responses during intragastric titration at $\mathrm{pH} 2 \cdot 5$ and 5.5 were compared in normal subjects and duodenal ulcer patients with G-cell hyperfunction. The latter were identified on the basis of raised basal or maximal acid outputs and increased gastrin responses to feeding. In normal subjects the mixed amino acid meal stimulated only modest increases in serum gastrin, and the highest observed increase was about $30 \%$ that after a standard meal. In contrast, in the G-cell hyperfunction group the highest gastrin concentrations were similar to those after a standard meal. In the G-cell hyperfunction group the increment in serum gastrin at $\mathrm{pH} 2.5$ expressed as a proportion of that at $\mathrm{pH} 5.5$ was 0.29 indicating that the capacity of acid to inhibit gastrin release was well established in these patients. Acid secretory rates were close to maximal at both $\mathrm{pH} 2.5$ and 5.5 during intragastric titration in the ulcer patients, but in normal subjects acid output was about $50 \%$ maximal at 2.5 and close to maximal at 5.5. The results suggest that the enhanced gastrin response to feeding in G-cell hyperfunction patients is because of increased sensitivity to amino acid stimulation rather than to diminished acid-inhibitory mechanisms.

Duodenal ulcer is likely to be a common end result of a heterogeneous group of disorders. Subgroups of duodenal ulcer patients have been identified on the basis of genetic, epidemiological, pathophysiological, and immunological criteria. ${ }^{1-3}$ One such subgroup includes patients with hypergastrinaemia and acid hypersecretion. ${ }^{4-6}$ In at least a proportion of these patients, first degree relatives also show increased gastrin responses to feeding and raised serum pepsinogen (which is directly related to maximal acid output). ${ }^{6} \mathrm{We}$ found that antral gastrin concentrations and G-cell numbers were normal in two patients belonging to this group, suggesting that the raised serum gastrin was because of G-cell hyperfunction, rather than hyperplasia. ${ }^{6}$ Acid normally inhibits gastrin release so that the combination of increased acid output and raised serum gastrin is inappropriate. There is evidence that in duodenal ulcer patients the mechanisms of acid-inhibition of gastrin release may be defective ${ }^{7}$ and this could obviously account for the increased

Address for correspondence: Dr G J Doc!:ray, Physiological Laboratory, University of Liverpool, Brownlow Hill, PO Box 147, Liverpool L69 3BX Received for publication 18 May 1984 serum gastrin in patients with G-cell hyperfunction. It is also possible, however, that the G-cells in the latter patients are more sensitive to stimulation. In the present series of experiments we have examined these possibilities by comparing the gastrin and acid secretory responses with intragastric instillation of a mixture of amino acids in normal and G-cell hyperfunction patients; the technique of intragastric titration ${ }^{8}$ was used to maintain a constant gastric $\mathrm{pH}$ at either 2.5 or 5.5 , so that the effects of acid inhibition could be directly examined. The results do not support the idea of impaired acid inhibition of gastrin release in the G-cell hyperfunction group, but instead point to increased sensitivity of the G-cell to amino acid stimulation.

\section{Methods}

\section{PATIENTS}

Five patients (four men, one woman, Table) with G-cell hyperfunction were identified among a group of patients with endoscopically proven duodenal ulcer. The criteria for inclusion in the G-cell hyperfunction group were as follows: (a) basal 
Table Basal and maximal acid output and basal serum gastrin of the subjects used in this study

\begin{tabular}{|c|c|c|c|c|c|}
\hline Subjects & Sex & Age & $\begin{array}{l}\text { BAO } \\
\text { (mmolih) }\end{array}$ & $\begin{array}{l}M A O \\
(\mathrm{mmol} / \mathrm{h})\end{array}$ & $\begin{array}{l}\text { Basal } \\
\text { gastrin } \\
\text { (pmolll) }\end{array}$ \\
\hline \multicolumn{6}{|c|}{ Normal subjects } \\
\hline C & $F^{\prime}$ & 25 & $0 \cdot 1$ & $14 \cdot 4$ & 40 \\
\hline F & $\mathbf{M}$ & 30 & $5 \cdot 0$ & $17 \cdot 0$ & 35 \\
\hline $\mathbf{R}$ & $\mathbf{M}$ & 25 & 1.8 & $11 \cdot 1$ & 19 \\
\hline$G$ & $\mathbf{M}$ & 28 & 4.9 & $29 \cdot 2$ & 17 \\
\hline $\mathbf{J}$ & $\mathbf{F}$ & 25 & $7 \cdot 8$ & $20 \cdot 9$ & 20 \\
\hline \multicolumn{3}{|c|}{ Mean \pm SE } & $3 \cdot 9 \pm 1 \cdot 3$ & $18 \cdot 5 \pm 3 \cdot 1$ & $26 \cdot 4 \pm 4 \cdot 8$ \\
\hline \multicolumn{6}{|l|}{ Patients } \\
\hline $\mathbf{M}$ & $\mathbf{M}$ & 22 & $22 \cdot 0$ & $36 \cdot 0$ & 64 \\
\hline G & $\mathbf{M}$ & 22 & $19 \cdot 3$ & $39 \cdot 4$ & 88 \\
\hline W & $\mathbf{M}$ & 2.3 & $14 \cdot 6$ & $37 \cdot 4$ & 32 \\
\hline $\mathrm{H}$ & $\mathbf{F}$ & 27 & $10 \cdot 0$ & $37 \cdot 0$ & 37 \\
\hline C & $\mathbf{M}$ & 25 & $11 \cdot 0$ & $22 \cdot 8$ & 48 \\
\hline \multicolumn{3}{|c|}{ Mean \pm SE } & $15 \cdot 3 \pm 2 \cdot 3$ & $34 \cdot 5 \pm 3 \cdot 0$ & $53 \cdot 8 \pm 10 \cdot 2$ \\
\hline
\end{tabular}

serum gastrin greater than $30 \mathrm{pmol} / \mathrm{l}$ and the peak increment in serum gastrin after a standard meal greater than $100 \mathrm{pmol} / \mathrm{l}$; (b) basal acid output greater than $10 \mathrm{mmol} / \mathrm{h}$ and maximal acid output following pentagastrin $(6 \mu \mathrm{g} / \mathrm{kg})$ either greater than $35 \mathrm{mmol} / \mathrm{h}$ or the ratio of basal to maximal greater than $0 \cdot 45$. In our laboratory $90 \%$ of duodenal ulcer patients show an increment in gastrin after feeding of less than $90 \mathrm{pmol} / \mathrm{l}$. The standard meal used for the gastrin studies consisted of two hard boiled eggs, one piece of toast and $120 \mathrm{ml}$ beef bouillion (Oxo) eaten over a period of 10 minutes; serum was taken for gastrin at 20,30 , and 40 minutes after the meal. None of the patients in this study had recent complication by haemorrhage, perforation or pyloric stenosis, nor had they had previous gastric surgery or vagotomy; only one had active ulcer disease within two months of study. For this patient, antacid, and $\mathrm{H}_{2}$-receptor antagonist therapy was discontinued 72 hours before the studies. None of the other patients were receiving treatments at the time of study. The normal subjects (three men, two women, mean age 27 years) were laboratory or hospital workers and did not have a history of gastrointestinal disease (Table). All subjects gave informed consent, and the study was approved by the local ethical committee.

INTRAGASTRIC TITRATION

All subjects fasted from midnight before the test. A trilumen orogastric tube was positioned along the lesser curve as far as the antral region, and the position confirmed by radiography. One lumen opened in the fundus and was used to deliver the initial bolus of amino acids and thereafter to maintain a constant delivery of amino acids and sodium bicarbonate, and for returin of the gastric contents removed for $\mathrm{pH}$ sampling. A second multi-fenestrated lumen was used for continuous sampling of the gastric contents by aspiration, and a third tube was used for equilibration of gastric and atmospheric pressure. A system of continuous circulation through the stomach was used with a separation of approximately $20 \mathrm{~cm}$ between inflow and outflow portals. Subjects sat upright at $45^{\circ}$ and turned onto their right side, this ensured good mixing as indicated by steady rates of bicarbonate delivery and a prompt increase on changing from $\mathrm{pH}$ 2.5 to $5 \cdot 5$. The $\mathrm{pH}$ of the gastric contents was monitored continuously (Radiometer, Copenhagen) and sodium bicarbonate $(8.4 \%)$ added to the delivery side at a rate sufficient to maintain $\mathrm{pH}$ at 2.5 during the first hour and 5.5 during the second hour. At the start of the experiment $200 \mathrm{ml}$ of amino acid solution was instilled into the stomach and the same solution was then infused continuously at 4 $\mathrm{ml} / \mathrm{min}$. The solution consisted of $20 \mathrm{~g}$ of Aminutrin amino acid powder (Geislick) dissolved in 1 litre of distilled water and supplemented with $1 \%$ tryptophan. The osmolarity was adjusted to $325 \mathrm{~m}$ Osmol $/ \mathrm{kg}$ by addition of $\mathrm{NaCl}$. The $\mathrm{pH}$ of the solution used during the first hour was adjusted to $2 \cdot 5$. At the end of this period the solution was removed and replaced with $200 \mathrm{ml}$ of the same amino acid solution adjusted to $\mathrm{pH} 5 \cdot 5$.

\section{GASTRIN RADIOIMMUNOASSAY}

Serum samples were taken every 10 minutes during the titration and stored at $-20^{\circ} \mathrm{C}$ before radioimmunoassay. Gastrin was measured by radioimmunoassay using a C-terminal specific antiserum, 1296 , according to published methods. ${ }^{9}$ Routinely serum was assayed at a final dilution of $1: 40$, but samples from the G-cell hyperfunction group that contained high concentrations of gastrin were frequently assayed at dilutions of $1: 100$ as well.

\section{STATISTICAL ANALYSIS}

Results are expressed as mean value \pm standard errors. The differences between the two groups were compared by Student's $t$ test.

\section{Results}

Gastrin responses to the intragastric instillation of amino acids were significantly greater in the ulcer compared with the control group at all times $(p<0 \cdot 05)$. In the normal subjects, the increase in serum gastrin was significantly greater than basal $(\mathrm{p}<0.05)$ only during titration at $\mathrm{pH} 5.5$ when it amounted to about $25 \%$ of the response to a standard meal (Fig. 1). In contrast, in the G-cell 


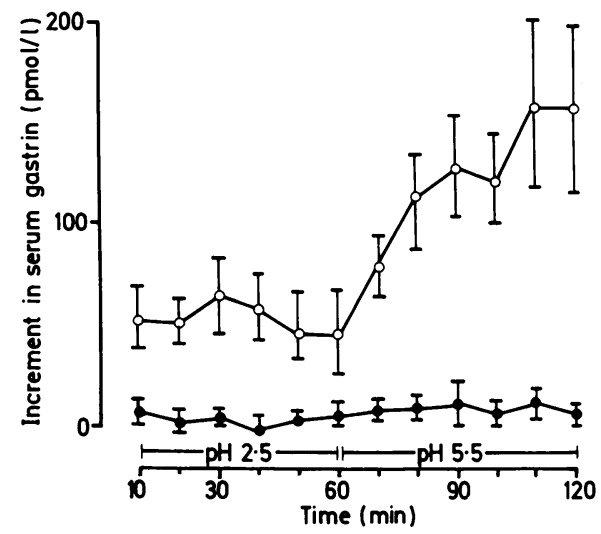

Fig. 1 Serum gastrin concentrations measured by radioimmunoassay during the course of intragastric titration in normal subjects (O) and $G$-cell hyperfunction patients (O). The increase in gastrin concentrations over basal is shown as the mean $\pm S E$ (indicated by vertical bars) for the two groups. For the first hour intragastric $\mathrm{pH}$ of the amino acid solution was maintained at $2 \cdot 5$, and for the second hour it was maintained at $5 \cdot 5$ (see Methods for further details). To the right is shown the peak gastrin response to a standard test meal taken on a separate day. Basal gastrin concentration in the normal subjects was $26 \cdot 4 \pm 4.8 \mathrm{pmol} / \mathrm{l}$ and in the $G$-cell hyperfunction patients was $53 \cdot 8 \pm 10 \cdot 2$ pmolll.

hyperfunction group the increase in serum gastrin was significant at both $\mathrm{pH} 2.5$ and 5.5. At the lower $\mathrm{pH}$ the increase was $30 \%$ of the response to a standard meal, and at $\mathrm{pH} 5.5$ the increase in serum gastrin was $112 \%$ that in the same subjects after a standard meal. When the gastrin response at $\mathrm{pH} 5 \cdot 5$ was expressed as a proportion of that to the standard meal the difference between the two groups was statistically significant at all times $(p<0 \cdot 05)$. An index of the inhibitory effects of acid on gastrin release may be obtained from the ratio of responses at $\mathrm{pH} 2.5$ and 5.5 (taking the response as the mean of the last three 10 minute periods at each $\mathrm{pH}$ ). In the G-cell hyperfunction group the increment in serum gastrin at $\mathrm{pH} 2.5$ was $0.29 \pm 0.076$ that at $\mathrm{pH}$ $5 \cdot 5$.

Intragastric instillation of amino acids stimulated acid secretion in all subjects. The acid secretion in the G-cell hyperfunction group was significantly greater than in the control subjects at all times $(p<0.05)$. In the normal group the highest rate of secretion at $\mathrm{pH} 2.5$ (mean of the two consecutive highest 10 minute periods) was $62 \pm 12 \%$ of maximal acid output to pentagastrin; at 5.5 the highest rate of secretion was $135 \pm 36 \%$ of the maximal acid output (Fig. 2) and these values were significantly different

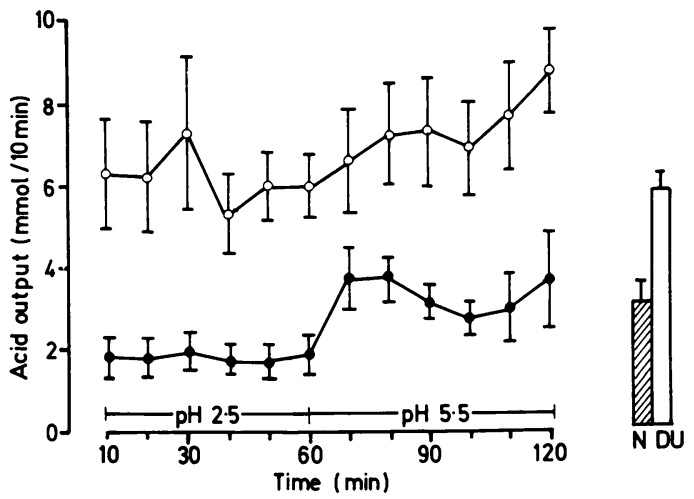

Fig. 2 Acid secretion during intragastric titration at $2 \cdot 5$ and 5.5 in normal and $G$-cell hyperfunction subjects. The rate of acid secretion was estimated from the delivery of sodium bicarbonate needed to keep intragastric $\mathrm{pH}$ constant. To the right is shown the maximal acid output determined in a pentagastrin test on a separate day. Basal acid output was $3.9 \mathrm{mmol} / \mathrm{h}$ in normal subjects and $15 \cdot 3 \pm 2 \cdot 3 \mathrm{mmol} / \mathrm{h}$ in the $G$-cell hyperfunction patients. See Fig. 1 for further details and for symbols.

$(p<0 \cdot 05)$. In the G-cell hyperfunction group the highest rate of acid secretion at $\mathrm{pH} 2.5$ was $124 \pm 18 \%$ of maximal acid secretion following pentagastrin (Fig. 2), and at $\mathrm{pH} 5.5$ it was $142 \pm 11 \%$; these values were not significantly different.

\section{Discusion}

The existence of a subpopulation of duodenal ulcer patients with raised acid output and exaggerated plasma gastrin responses to feeding has been recognised for some time. ${ }^{4-6}$ The circulating gastrin is primarily of antral origin as antrectomy reduces the gastrin response to feeding. ${ }^{46}$ The term G-cell hyperfunction offers a convenient operational definition for this group of patients; although it is possible that some of these patients may have G-cell hyperplasia, ${ }^{10}$ others have a normal density of G-cells. ${ }^{6}$ Acid normally inhibits gastrin release and a failure of this mechanism would obviously account for the hypergastrinaemia in G-cell hyperfunction. In the present study we examined this possibility by comparing gastrin responses in normal and G-cell hyperfunction patients during intragastric instillation of amino acids when $\mathrm{pH}$ was maintained constant at 2.5 or 5.5 by addition of sodium bicarbonate. The results do not support the idea that there is a defective acid inhibitory mechanism in G-cell hyperfunction patients, but instead they 
suggest that gastrin cells might be particularly sensitive to certain modes of stimulation in these patients.

The results obtained with control subjects in the present study are broadly comparable with those of Walsh et al. ${ }^{7}$ who used an amino acid solution similar to that used by us but supplemented with cornstarch. In both studies there was little gastrin release at $\mathrm{pH} 2.5$ in normal subjects, and at 5.5 the gastrin response was $30-50 \%$ that to a mixed meal (homogenised steak was instilled intragastrically by Walsh et al, compared with eggs and meat extract taken in the normal way in the present study). In an unselected group of duodenal ulcer patients studied by Walsh et al there was significant secretion of gastrin at $\mathrm{pH} 2 \cdot 5,{ }^{7}$ and in the G-cell hyperfunction patients studied here there was again significant secretion of gastrin at this $\mathrm{pH}$. There were, however, differences in the degree of inhibition of gastrin release at $\mathrm{pH} 2.5$ compared with 5.5 , in the two groups of ulcer patients. Thus in the ulcer patients studied previously there was only about $30 \%$ inhibition of gastrin release at $\mathrm{pH} 2.5$ compared with $5 \cdot 5,^{7}$ whereas in the present study there was about $70 \%$ inhibition of gastrin release at 2.5 compared with $5 \cdot 5$. The latter is similar to that reported for normal subjects. ${ }^{7}$ Evidently, then, in the selected group of ulcer patients used in the present study the inhibitory effects of acid on gastrin release were much better developed than in the duodenal ulcer patients studied by Walsh et al. Moreover, the results suggest that the principal defect in gastrin release in the G-cell hyperfunction patients lies not in resistance to acid inhibition, but rather in sensitivity to stimulation by amino acids. In particular, when intragastric $\mathrm{pH}$ was held at $5 \cdot 5$ (thereby eliminating acid inhibition) the mixture of amino acids used by us evoked an increase in serum gastrin in the G-cell hyperfunction patients that was comparable with the response to a standard meal, while in normal subjects the response to amino acids was only $25 \%$ of that to the meal.

The meal used by us evoked about $50 \%$ of maximal acid output at $\mathrm{pH} 2.5$ in normal subjects. As the rise in gastrin at this $\mathrm{pH}$ was not significant, it seems that non-gastrin mediated pathways are likely to be involved. In the ulcer group the acid response at $\mathrm{pH} 2.5$ was near maximal. This might be because of enhanced activity of the non-gastrin mediated mechanisms of acid stimulation, but circulating gastrin could also make a significant contribution to this acid response.

Among the pathophysiological changes involving acid and gastrin in duodenal ulcer patients, previous studies have implicated enhanced gastrin-responses to feeding, decreased acid-inhibition of gastrin release, increased sensitivity to circulating gastrin and increased acid secretory capacity. ${ }^{257} 7_{1}$ Not all these abnormalities apply to all duodenal ulcer patients, and some progress has already been made toward the identification of distinct subgroups of ulcer patients on the basis of their acid or gastrin responses to stimulation.5 1213 These studies. however, have not for the most part involved control of intragastric $\mathrm{pH}$, and as a consequence the effects of acid inhibition could not be separated from those of increased sensitivity of G-cells to stimulation. The control of intragastric $\mathrm{pH}$ by titration in the present study has therefore allowed us, for the first time, to add increased sensitivity of gastrin to stimulation by amino acids to the list of abnormalities shown by a definable subgroup of duodenal ulcer patients. It seems likely that these patients produced exaggerated gastrin responses to modest levels of stimulation. which in turn cause exaggerated acid responses. The gastrin responses to luminal stimulation might involve direct action of luminal stimuli on the apical portions of G-cells, or indirect effects mediated by gastric neurones. The precise mechanisms involved in the control of gastrin release in G-cell hyperfunction patients now need to be established.

We are grateful to the MRC for financial support. It is a pleasure to record our thanks to Carol Higgins and Hilary Smith for skilled technical assistance with gastrin assays, and to Brenda Harris for help with acid secretory tests.

\section{References}

1 Rotter JI, Rimoin DL. Peptic ulcer disease - a heterogeneous group of disorders? Gastroenterology 1977: 73: 604-7.

2 Grossman MI. Abnormalities of acid secretion in patients with duodenal ulcer. Gastroenterology 1978; 75: $524-6$.

3 Rotter JI. Gastric and duodenal ulcer are each many different diseases. Dig Dis Sci 1981: 26: 154-60.

4 Lamers CBH. Ruland CM. Joosten HJM, Verkooyen HCM. Van Tongeren JHM, Rehfeld JF. Hypergastrinemia of antral origin in duodenal ulcer. Dig Dis 1978; 23: $998-1002$.

5 Walsh JH, Lam SK. Physiology and pathophysiology of gastrin. Clin Gastroenterol 1980; 9: 567-91.

6 Taylor IL. Calam J, Rotter JI et al. Family studies of hypergastrinemic, hyperpepsinogenemic I duodenal ulcer. Ann Intern Med 1981; 95: 421-5.

7 Walsh JH, Richardson CT. Fordtran JS. pH dependence of acid secretion and gastrin release in normal and ulcer subjects. J Clin Invest 1975; 55: 462-8.

8 Fordtran JS. Walsh JH. Gastric acid secretion rate and 
buffer content of the stomach after eating. Results in normal subjects and in patients with duodenal ulcer. $J$ Clin Invest 1973; 52: 645-57.

9 Dockray GJ, Walsh JH. Amino terminal gastrin fragment in serum of Zollinger-Ellison syndrome patients. Gastroenterology 1975; 68: 222-30.

10 Polak JM, Stagg B, Pearse AGE. Two types of Zollinger-Ellison syndrome: immunofluorescent, cytochemical and ultrastructural studies of the antral and pancreatic gastrin cells in different clinical states. Gut 1972; 13: 501-12.

11 Lam SK, Isenberg JI, Grossman MI, Lane WH, Walsh
JH. Gastric acid secretion is abnormally sensitive to endogenous gastrin released after peptone test meals in duodenal ulcer patients. J Clin Invest 1980; 65: 555-62.

12 Lam SK, Ong GB. Relationship of postprandial serum gastrin response to sex, body weight, blood group status, familial dyspepsia, duration and age of onset of ulcer symptoms in duodenal ulcer. Gut 1980; 21: 528-32.

13 Byrnes JD, Lam SK, Sircus W. The relation between functioning parietal cell and gastrin cell masses in two groups of duodenal ulcer patients. Clin Sci Mol Med 1976; 50: 375-83. 